\title{
Organisational leadership and/for sustainability: future directions from John Dewey and social
}

\section{movements}

\section{Brian Howieson, Bernard Burnes and Juliette Summers}

\begin{abstract}
In this paper, we suggest that organisational leadership that is based (generally) on a neoliberal paradigm has contributed to an 'intolerable situation' that was recognised at the United Nations (2015a) Paris Agreement on Climate Change. We, therefore, attempt to re-frame organisational leadership based on a sustainability paradigm. In doing so, we draw on John Dewey's thinking on publics: due to the need for greater stakeholder involvement in identifying how sustainability could be achieved and increasing pressure from governments, campaigning groups and public opinion for organisations to expand their boundaries further to interact with, and take seriously, the needs of the communities that they affect. Then-and for the implementation of this re-frame and cognizant of the community requirement-we will offer that guidance may be drawn from the emerging social movements literature, specifically the importance of narration, mobilisation and organisation. Finally, we present a revised framework for organisational leadership that is based on this sustainability paradigm.
\end{abstract}

\section{Keywords:}

Leadership, Framing, John Dewey, Social Movements 
'If we determine that leadership is in our hands and minds to change, what shall we do with it? Are we happy with it as it currently stands? Is it serving to advance our civilization in a way that is sustainable to ourselves and to our off spring?'

Joseph A Raelin, 2016

\section{Introduction}

Since the 1970s, governments and organisations have been driven by a neoliberal leadership paradigm that prioritises the pursuit of profit through free markets, private enterprise, deregulation and a reduction in state power, taxation and expenditure (Chomsky, 1999; Stiglitz, 2010). Its rationale is that society works best when people, organisations and governments operate on a free market basis, and leaders are motivated by the pursuit of profit, which is seen not just as a common good but as the prime and possibly the only common good (Friedman, 1970; Harvey, 2005).

The UN and many others now believe, however, that there is incontrovertible evidence that the untrammelled pursuit of ever-greater profit is driving the rapid depletion of natural resources, increased pollution and run-away climate change (Benn et al, 2014; Carbo et al, 2014; Harvey, 2015; Hasina, 2016; IPCC, 2014; Lombardo et al, 2013; United Nations, 2015a; WWF, 2014). Although there have been attempts to take a neoliberal approach to tackling sustainability (for example, carbon trading), these tend to be controversial because they are based on the same profit-driven philosophy that brought unsustainable development (Gilbertson and Reyes, 2009; Mathur et al. 2014).

Just as importantly, and from a UN perspective, such attempts are based on a very narrow view of sustainability. Of note, the UN sees sustainability as being concerned with not just tackling the rapid depletion of natural resources but also ensuring their fair distribution-especially to the world's poor (Gladwin et al. 1995; The Brundtland Report, 1987; United Nations, 2010 \& 2015b). Therefore, and in using this broad measure of sustainability, profitability ceases to be the sole mediator of right and 
wrong. Instead, it becomes one of the three Ps of triple bottom line environmental accounting, i.e. People, Planet and Profit (Prosperity) (Elkington, 1994; Elkington and Hartigan, 2008; Fry and Nisiewicz, 2013). In this respect, instead of Profit being the paramount objective of private sector organisations, leaders (of these organisations)—in seeking to contribute to sustainability—will also have to ensure that their actions (i.e. corporate behaviour) have a beneficial effect on Planet and People. The need, then, to 'rein in' this pursuit of profit is, perhaps, a key reason why many now argue that neoliberalism and sustainability are incompatible (Chomsky, 1999; Freeman et al. 2010; Harvey, 2005; Stiglitz, 2010). Therefore, we argue in this paper for the need to replace, or re-frame, the current neoliberal paradigm with a sustainability paradigm. Moreover, we suggest that the current framing of organisational leadership—which is based (generally) on this neoliberal paradigm—has contributed to what social movement theorists $(\mathrm{Ganz}, 2008)$ refer to as an 'intolerable situation' i.e. ever-increasing levels of consumption threaten to destroy global sustainability, which is what the UN's Paris accord sought to address (United Nations, 2015a).

Going forward-and echoing the views of Professor Jeffrey Sachs, Director of the Centre for Sustainable Development at the Earth Institute, when he said in 2015: 'The diplomats have done their job: the Paris Agreement points the world in the right direction, and with sophistication and clarity. It does not, however, ensure implementation, which necessarily remains the domain of politicians, businessmen, scientists, engineers, and civil society'-we consider that these people (politicians, businessmen, scientists, engineers and civil society) now need to implement this new frame of organisational leadership that is based on a sustainability paradigm. ${ }^{1}$

In addition, as the Paris Agreement has signalled, there is pressure from governments, campaigning groups and public opinion for organisations to expand their boundaries even further to interact with—and take seriously - the needs of the communities that they affect. In addressing this issue, and in seeking to re-frame organisational leadership, we draw on Dewey's (1927) work on publics, which, we consider, is consistent

\footnotetext{
${ }^{1}$ Prof. Jeffrey Sachs, Director of the Centre for Sustainable Development at the Earth Institute, quoted in the Financial Times, 12/12/2015.
} 
with the need for involving greater stakeholder involvement in identifying how sustainability could be achieved (Burnes, 2017a; Raelin, 2016). For Dewey (1927:15-16), a 'public consists of all those who are affected by the indirect consequences of transactions to such an extent that is it deemed necessary to have those consequences systematically cared for'. Therefore, a public is a social grouping who, in facing a similar problem, recognise it and organise themselves to address it, which is, of course, what has been occurring across the globe as a wide variety of groups have mobilised to campaign for a sustainable world (Klein, 2015). In effect, these are social movements, which are characterised by four core activities: framing, narration, mobilising and organising (Boyd et al. 2013; Ganz, 2008, 2010; Sutherland, 2015; Wahie et al. 2016).

In this paper, we will argue that to address the intolerable situation posed by the threat to global sustainability, we need to draw on a social mobilisation approach to re-frame how we perceive leadership and that this can be pursued by a renewed leadership narrative, which can be implemented by mobilisation and organisation. ${ }^{2}$

Our contribution is, therefore, threefold: first, we will argue that a new paradigm, and one based on sustainability, is required; second, we will attempt to re-frame leadership—at the organisational level of analysis (Yukl, 2012)—and based on the work of John Dewey; and third, such organisational leadership may be implemented by the approach used currently by social movements.

In making the case for this new organisational leadership model, this paper will proceed as follows. First, we will explore briefly how paradigms arise. Second, we will look at the creation of the current neoliberal paradigm. Third, we will review the current situation based on this current neoliberal paradigm. Fourth, we will offer a new framing of organisational leadership based on the work of John Dewey. Fifth, we will suggest that this reframing will need to be narrated by all associated with

\footnotetext{
2 'Social Movements stand in stark contrast to the structures of more "conventional" organisations: stressing the importance of leaderslessness, horizontality, widespread participation, democracy and antiauthoritarianism'. (Sutherland, 2015: 213))
} 
leadership and its development. Penultimately, we will discuss how this reframing can be mobilised. Finally, we suggest how it may be organised.

\section{What is a Paradigm?}

Although he did not invent the word, it was the American philosopher of science Thomas Kuhn (1962) who, in his book The Structure of Scientific Revolutions, gave a new importance to the notion of 'paradigms'. He defined a paradigm as a universally recognised scientific achievement that over a period of time provides model problems and solutions to a community of practitioners. Kuhn was interested in how new ideas and frameworks for carrying out scientific work (i.e. paradigms) supplant old ones in the physical sciences. From the late 1960s onwards, a growing body of social scientists adopted the Kuhnian approach to their own disciplines with great enthusiasm.

As far as its applicability to organisations is concerned, a paradigm can be defined as a way of looking at and interpreting the world—a framework of basic assumptions, theories and models that are commonly and strongly accepted and shared within a field of activity at a point in time (Collins, 1998; Mink, 1992; Reed, 1992). Of note, as situations change and people's perceptions change, existing paradigms lose their relevance and new ones emerge.

\section{The Creation of a Neoliberal Leadership Paradigm}

It was in the USA that the current neoliberal leadership paradigm first became apparent. It was the rise of Japanese industrial and economic might that forced American businesses to question what they did and how they did it. As Morgan (1986: 111) relates:

During the 1960s, the confidence and impact of American management and industry seemed supreme. Gradually, but with increasing force, through the 1970s the performance of Japanese 
automobile, electronic and other manufacturing industries began to change all this. Japan began to take command of international markets.

The productivity gap between Japanese and American companies was starkly highlighted in a Harvard Business Review article by Johnson and Ouchi (1974). These authors claimed that Japanese workers-assembling the same product using the same technology-were 15 per cent more productive than their American counterparts.

Nor was it just the Japanese challenge that frightened the West. The 1970s also saw the return of unemployment and inflation and the occurrence of two 'oil shocks', which highlighted most Western nations' precarious reliance on imported energy (Kemp, 1990). Therefore, old certainties were being challenged and new orthodoxies began to arise. Rather like Copernicus, Japan made the West see the world and its place in it from a new perspective. In effect, in the last 30 years or so, the world has turned on its axis (Fruin, 1992). The days of the mass production of standardised products appear to be over-the key words now are variety, flexibility and customisation (Masayuki, 1998).

The move, then, to a new leadership paradigm was driven by the advent of Milton Freeman's monetarist theory of economics. Simply put, monetarism—which is closely aligned with neoliberalism-maintains that the market should be the main arbiter of economic performance and that governments should have only a minimal role in how private enterprises should operate (Vaggi and Groenewegen, 2003). Monetarism and neoliberalism laid the groundwork for the rise of a generation of organisational leaders who saw profit not so much as their prime objective, but their only objective (Chomsky, 1999; Stiglitz, 2010; Storey, 2004).

In order to counter this, we need to draw on approaches to leadership that are consistent with and help to justify the role of a broader group of stakeholders, what Dewey (1927) refers to as a 'public'. 


\section{Replacing the Current Neoliberalism Paradigm with a Sustainability Paradigm: Understanding and Addressing an Intolerable Situation}

\subsection{John Dewy and Publics}

As a 'leadership-for-sustainability' frame requires a broadening out of power to include all those affected by this sustainability crisis, we suggest that a Deweyan publics discourse can provide a useful vocabulary for exploring a sustainability frame. Dewey argued that the consequences of an act-for example, an organisational leadership decision—can impact significantly not only on those directly undertaking the act but also on others (Sugden, 2010). The interests of the direct participants in this act are said to be private, whereas those of the others (i.e. those affected by the act) are public. We, therefore, consider that a neoliberal framing of leadership encourages the pursuit of private interests that can, and do, override the interests of publics.

For Dewey, a public has 'a shared concern' with the consequences of, for example, leadership practice and 'a common interest in controlling these consequences' (1927: 126). Dewey draws attention to four types of publics: non-publics (who have no problem), latent publics (who have a problem), aware publics (who recognise that they have a problem), and active publics (who do something about their problem) (Grunig, 1983). ${ }^{3}$ In terms of sustainability, we are seeing the increasing appearance of these latter two publics. As The Economist (2018) states: 'As global political shifts start to revise the world order, the role of citizens, businesses and policy makers in the pursuit of the green agenda is also evolving'.

As a consequence, the discontent with the classical perspective on leadership, which sees leadership roles and individual leadership as synonymous, is being challenged and replaced by the notion of leadership as a plurality of processes (Crevani et al, 2010). It should be noted, though, that while these

\footnotetext{
${ }^{3}$ In public relations and communication science, publics are groups of individual people and the public (a.k.a. the general public) is the totality of such groupings.
} 
new approaches incorporate collective aspects of leadership (Castell, 2012; Raelin, 2016), they still tend to frame leadership as something bounded and controlled by organisational members. This, of course, is not consistent with the need for the pursuit of sustainability, which requires leadership to be jointly held by the 'publics' and not solely a property of individual leaders and individual organisations.

Thus, the pursuit of sustainability will require leaders to expand their boundary-spanning role (s) to embrace a wide range of internal and external stakeholders or, to put it another way, widespread participation in decision-making will be required if a clear, achievable and effective sustainability agenda is to be constructed and implemented (Burnes, 2017a).

\subsection{The Nature of Sustainability}

One of the most significant developments for organisations over the last two decades has been the growing acceptance that ever-increasing levels of consumption have created an 'intolerable situation' that threatens to destroy global sustainability (Benn et al. 2014; Bonini and Bové, 2014; Piasecki, 2012; WWF, 2014). The clearest indication of this was the outcome of the December 2015 Paris UN Conference on Climate Change, which signalled that radical changes in human behaviour are necessary if the worst consequences of unsustainable development are to be avoided (Harvey, 2015; Hasina, 2016).

The Paris negotiations resulted in a global agreement that limited global warming to under $2^{\circ} \mathrm{C}$. This agreement has, however, little enforcement power. Without a global enforcement mechanism, the need for systems change becomes ever more significant; therefore, organisations (and their leadership) will play a key role in achieving the Paris 2015 targets (Benn et al. 2014; Dunphy and Griffiths, 1998; Gunter, 2015). However, as Burnes (2017a: 337) maintains, pursuing sustainability 'will require significant changes to corporate behaviour which, as corporate behaviour is embedded 
in an organisation's culture, will require organisations to change their culture or at least a significant aspect of it'.

More generally, the UN's Paris agreement on climate change has highlighted two key organisational issues that the leaders of these organisations will need to address and which, as we will argue, current organisational approaches to leadership have little to offer:

- $\quad$ The clash between profit and sustainability demonstrates a classic 'tragedy of the commons' (Hardin, 1968; Hess, 2008). Using a hypothetical group of herders who share common grazing land, Hardin (1968) predicted that the pursuit of private interest would result in enough herders seeking to maximise their individual benefits by over-grazing the land with ever bigger herds of livestock, while the cost of over-grazing would be shared by all.

- The worldwide protests that accompanied the Paris negotiations (such as the 'No Planet B' movement) indicate global recognition of this as a 'collective problem'. Put another way, societal interests (activated by a concern with climate change) have articulated a negative externality produced by organisational leadership - that of climate change driven by industrial/commercial pollution.

It should be noted further that sustainability embraces a wide range of complex, ambiguous and seemingly conflicting social, ecological and economic factors (Hall and Vredenburg, 2003; Montiel and Delgado-Ceballos, 2014; Valente, 2012). The most widely accepted definition of sustainability comes from the report of the World Commission on Environment and Development (The Brundtland Report, 1987: 41), which states that sustainability is:

Development that meets the needs of the present without compromising the ability of future generations to meet their own needs. It contains within it ... the concept of 'needs', in particular the essential needs of the world's poor, to which overriding priority should be given. 
Furthermore, the UN's target of achieving its sustainable development goals by 2030 (United Nations, 2015b) requires us all, especially organisations, to focus on people, planet and prosperity rather than just profit. Taken together, we suggest that these sustainability definitions and goals will require a redistribution of power: 'from power-over to power-with and for others' (Ricoeur, 1992:172). However, in this regard, it must also be recognised that there are significant differences between the UN's broad view of sustainability and the narrower view taken by many in the business world who tend to focus more on the unsustainability of resource use rather than the attendant equity and inclusiveness called for by the UN (Klein, 2015; Marshall and Toffel, 2005; WWF, 2014).

Of note, a world where organisations adopt sustainable development practices will be a different one to our current world where competitiveness and profitability have been inextricably linked to ever greater environmental depletion and damage (Benn et al. 2014). In understanding and accepting that this is key to achieving sustainability, organisational leadership will, therefore, need to see sustainability not just in terms of climate action, but in terms of the full range of the UN's sustainable development goals, including eradicating poverty and hunger, providing quality education for all and promoting peace and justice across the globe (United Nations 2015b). Though most organisations claim to be addressing sustainability issues (Ioannou and Serafeim, 2016), there is considerable doubt as to how serious many of them are or if they really understand the fundamental changes called for (Banerjee and Bonnefous, 2011; Harvey, 2015; Jones, 2012; Srinivasan and Rethinaraj, 2013). As Docherty et al (2002:12) note:

Sustainability ... encompasses three levels: the individual, the organisational and the societal. Sustainability at one level cannot be built on the exploitation of the others. These levels are intimately related to the organization's key stakeholders: personnel, customers, owners and society. Thus, sustainability has a value basis in the due considerations and balancing of different stakeholders' legitimate needs and goals. 
In this respect, Docherty et al (2002) argue that sustainability cannot be achieved unless all stakeholders are involved and all—including wider society—are treated in an equitable and ethical manner. At this juncture, then, we do wonder if all stakeholders are involved within the current organisational leadership model that is based on the neoliberal paradigm.

Therefore, and though governments are ratifying the Paris Agreement, ${ }^{4}$ its success relies on organisations changing their behaviour in a significant and urgent manner (Harvey, 2015; Hasina, 2016; Hockerts and Wustenhagen, 2010; Schaltegger et al (2012 \& 2013)). For most organisations, the pursuit of global sustainability will, therefore, require a fundamental shift in their values and leadership priorities in order to balance profitability with sustainability (Benn et al, 2014; Lombardo et al. 2013; Piasecki, 2012). In essence, this means—as Stiglitz claims (Martin, 2016) 一that organisations will be driven by a new set of values based on sustainability. It is this need for a fundamental shift in values that provides the rationale in rethinking organisational leadership and one based on a sustainability paradigm (Burnes et al. 2016; Carbol et al. 2014).

It follows, then, that in a world where sustainability rather than profit is becoming paramount—and, in the absence of effective enforcement for the Paris Agreement-there is a need for a new 'sustainable' approach to organisational leadership that embodies the unspoken values and systems that underpin it—essentially, how organisational leadership is 'framed', based on a sustainability paradigm. ${ }^{5}$

\subsection{Social Movements}

\footnotetext{
${ }^{4}$ See, for example: http://www.bbc.co.uk/news/world-europe-42322968

${ }^{5}$ Raelin (2016) also proposes a 'reframing' of leadership based on collaborative agency. We consider that we are talking about the same thing. He mentions (p131): 'Fearing that our overreliance on an individual, heroic model of leadership will only continue to dampen the energy and creativity of people in our organizations and communities, this essay proposes a practice perspective of leadership based on a collaborative agency mobilized through engaged social interaction'. The paper concludes by showing how the collaborative agentic model might produce a more sustainable future for our world while suggesting avenues for future research of a collective rather than a personal approach to leadership. We, however, argue for a reframing based on a sustainable paradigm.
} 
To understand how such a significant change to organisational leadership could then be implemented, we draw on Ganz's (2010) work on leadership as a social movement. As Ganz (2010:1) asserts, a social movement can be understood as the 'efforts of purposeful actors ... to assert new public values' in order to change an 'intolerable situation'-in this case, the ever-increasing levels of consumption that threatens to destroy global sustainability and the values which underpin the unsustainable development that is threatening global ecological catastrophe (Diamond, 2005; United Nations, 2015a; WWF, 2014).

In detail, Boyd et al (2013) state that social movements are based on four core activities:

- $\quad$ Framing

- $\quad$ Narration

- $\quad$ Mobilising

- $\quad$ Organising

So, at present, and based on this social movement approach, we suggest that the organisational leadership — and based on the neoliberal paradigm — may be represented by the framework in Table 1.

\begin{tabular}{|l|l|l|l|}
\hline Frame/Interest/Power & Narration/Publics & Mobilising & Organising \\
\hline Neoliberal and focused & The dominant (neoliberal) paradigm: & The alignment & Highly \\
on organisational & & of MNCs, & organised and \\
members and & Independent Variable (Leader) $\Longrightarrow$ Dependent Variable (Follower) & institutional & dominant \\
stakeholders/private/over & /Latent & investors, & governments, \\
& & grivate sector & \\
& & global & institutions \\
& & (such as the & \\
\hline
\end{tabular}




\begin{tabular}{|l|l|l|l|}
\hline & IMF and \\
WTO) and \\
educational \\
bodies, \\
especially \\
university \\
business \\
\hline
\end{tabular}

Table 1: Organisational Leadership and the Neoliberal Paradigm

\section{Re-framing Organisational Leadership: Developing a Shared Understanding of the Intolerable Situation}

Going forward, our analysis is at two levels: first, and at the organisational level (Yukl, 2012), we contend that leadership needs to be re-framed and based on a sustainability paradigm; and second, it is important that this 're-framing' is narrated, mobilised and organised by all stakeholders starting with the actors and decision-makers who can influence corporate behaviour. Such actors may include-but are not limited to-organisations such as the World Economic Forum, university business schools, and the Institute for Directors (to name but a few) and indeed all associated with leadership and its development.

We do, however, accept that 'narration' is taking place at present; for example, the recent (and third) The Economist (2018) Summit on Sustainability that had the strap line of 'From responsibility to leadership.' We argue, however, that a different narration-and based on a different framing of organisational leadership—needs to take place. At present, we consider that there is a lack of agency for society and for environmental systems (i.e. nature). It is here that we perceive the inherent contradiction between neoliberal leadership and leadership for sustainability. The former sees Profit 
as the main and unchallengeable measure of progress, whilst sustainability believes the pursuit of Profit must be seen in the context of the other two Ps - People and Planet. Given the collective impact of unsustainable organisational practices, we contend that dealing with sustainability is not just about environmental policy but about leadership and, essentially, how it is framed. In fact, Ghoshal et al's (1999) call to business leaders to recognise their social role is, we suggest, a call to reframe leadership. This is supported by the World Business Council's 'call for organisations to rethink their relationships with community stakeholders in the wake of a global financial crisis that has generated widespread economic, social and political dislocation'(Willis 2012:116). ${ }^{6}$ Although Case et al. (2015) argue that environmental leadership needs to be 're-thought' (for example, they say (p. 397): "narratives of environmental leadership remain relatively neglected in the academic literature'), we consider that this is not enough, rather it is a complete re-framing of leadership that is required and based on a sustainability paradigm.

Framing itself has been written about across many disciplines and genres. In environmental policy, for example, framing is used widely given the 'particularly contested and complex nature' of this field (Dovers (2005:62) and cited in Funfgeld and McEvoy (2014)). For Goffman (1974:10)—and in the field of sociology $-\mathrm{a}$ frame is a principle of organisation 'which governs the subjective meaning we assign to social events' and is a 'way of seeing' the world that allows identification and labelling of events and conditions. In a similar vein, Benford and Snow (2000) describe framing as 'meaning construction ... through which groups and individuals make sense of the world' and for Gitlin (1980:6), frames are 'principles of selection, emphasis and presentation composed of little tacit theories about what exists, what happens and what matters'.

Turning to the leadership-specific literature, Fairhurst (2005) discusses the art of framing and its implications to leadership. Of note, we are struck by her comment (p168) that 'our definition of framing within the leadership relationship is quite consistent with a perspective on power that is

\footnotetext{
${ }^{6}$ See also The Problem with Leadership at: https://www.thersa.org/discover/publications-and-articles/rsacomment/2014/04/the-problem-with-leadership
} 
never independent of its implementation'. We consider, then, that to tackle this 'intolerable situation', we will have to develop a new framing of leadership that is not anchored in such neoliberal values. To explore how this might be done, we return to John Dewey's thoughts on Publics.

In reflecting on the requirement of a redistribution of power-and incorporating Dewey's work into our re-framing of organisational leadership—we may acknowledge the agency of publics in regulating the consequences of an act that impacts upon them. Such regulation can be undertaken; we suggest, by both social and environmental publics, an approach already reflected in the work on Gaia by Lovelock and Margulis (1974), in Card's consideration of the agency of ecosystems (2004) and in Leopold's concern with land ethics (1949).

So, and at this stage, we can re-frame leadership as a collection of actors who face a similar problem, recognise the problem and organise themselves to do something about it. Moreover, and acknowledging the role of a collection of actors, leadership cannot be contained within organisations (i.e. the 'boundary problem') and exists not in individuals but in collective processes, capacities and interactions where leadership is a 'property and consequence of a community'-in other words, a public resource, "rather than the property and consequence of an individual leader' (Grint, 2005: 38) i.e. a private resource. This theme-the problem of individual agency-is also present in the work of Raelin (2016). For example, he says (page 147): 'It will certainly help to raise consciousness about possibilities — that our outcomes from leadership, as suggested above, might be far more sustainable when leadership is viewed as a plural phenomenon (Denis et al., 2012)'.

In this respect, it is interesting that throughout the various sustainability definitions on offer, a focus on the relational nature of a common interest can also be identified, which mirrors Cunliffe \& Eriksen's (2011: 1430) version of 'leadership as a way of being-in-relation-to-others'. This is similar to the argument of leadership as a collaborative agency (Raelin, 2016). 
Neoliberal (and perhaps 'exclusionary') leadership, as the regulation of a leadership resource by private interests, represents a private interest 'power-over' (Ricoeur, 1992) other publics, which can be either coercive or by consent. Underpinning such exclusionary leadership may be a latent public, one which 'does not recognise a situation as problematic' (Boje et al. 2004:753). To move, then, from a latent state to that of an aware public-one which has 'an awareness on the part of the members of the public that they constitute a public i.e. an awareness that they have an interest in common with one another' (Fott (1998:31) cited in Branston et al (2006:318))-requires access to information plus communicative opportunities to allow for the realisation and acknowledgement of a common interest. Ganz (2010) terms this 'narration'. This may be represented in Table 2.

\begin{tabular}{|l|l|}
\hline Frame/Interest/Power & Narration/Publics \\
\hline A collection of actors who face a similar problem, & Relational nature of a common interest /Aware \\
recognise the problem, and organise themselves & \\
to do something about it/Public/With and For & \\
\hline
\end{tabular}

Table 2: Narration

\section{Narration}

By replacing a neoliberal framing with a Dewey framing (i.e. leadership as a collection of actors who face a similar problem, recognise the problem and organise themselves to do something about it), emerging leadership concepts that are responding to the 'intolerable situation' of unsustainability can be re-narrated as part of a leadership approach to sustainability. Indeed, the requirements of sustainability challenge the primacy of the profit motive and the independence of individual organisation and seek to promote collaboration across a wide range of public, private and voluntary bodies (Burnes, 2017a). 
This collaboration is key. As Raelin (2016:136) notes:

\footnotetext{
We engage with one another not only to listen but to organize our ways of acting together (Hersted and Gergen, 2013). Change in organizational life occurs when people begin to talk diff erently, whether it be about the content of the conversation or its dynamics. Their talking may bring to light previously unnoticed patterns and allow the parties to fashion a scenic sense of their new circumstances (Shotter and Cunliffe, 2003). In the manner of the 'ironist', Rorty (1989) claims that cultural change occurs more from people speaking differently rather than arguing well.
}

Of note, Burnes (2017a) suggests that a significant barrier to change-to achieve sustainability-is corporate culture. Ultimately, leadership and, therefore, change to corporate culture becomes a consequence of collaborative 'meaning-making' in practice. In this way, it is intrinsically tied to a collective rather than to an individual model of leadership (Ospina and Foldy, 2010; Reckwitz, 2002).

\section{Mobilising}

Mobilisation, in the sense of a social movement, is concerned with building a critical mass, momentum and capacity to move 'people from bystander to participant' (Boyd et al. 2013: 15) through collective agency and utilisation of common resources. Indeed, Raelin (2016) suggests that leadership based on a collaborative agency is mobilised through engaged social interaction. In addition, Burnes (2017a) notes that organisations need the participation of all stakeholders to change. Other prominent organisations are now considering this too. For example, The Economist (third) Sustainability Summit (2018) will 'bring together business leaders, policy makers, scientists, advocates and investors to gauge the scale of the task and work out how best to lead and encourage co-operation on the path to progress'.

Relating this to Dewey's publics, it articulates the move from an aware public (i.e. one which has access to information plus communicative opportunities to allow the realisation and acknowledgement 
of a common interest) into an active public, one which then 'organizes to do something about a situation' (Boje et al. 2004: 753). Consequently, mobilisation is the acknowledgment, by publics, of their 'power-to-do' and to act (Ricoeur, 1992).

This mobilisation, we consider, is a key task for all leadership actors and decision-makers.

\section{Organising}

Organising is the collective acts of active publics, acting in, and for, their common interests and operationalising power 'with and for others' (Ricoeur 1992: 172). We suggest that this involves a change from a focus on corporate leaders' responsibility to engage stakeholders to publics' responsibility for leadership or as Raelin (2016: 141) says: 'The parties committed to a practice enter an authentic dialog to reproduce or transform the very practice in which they are engaged'. This is also echoed by Mintzberg (2016) who states: 'Concerned people will have to learn how to use disorganization to rebalance a world headed for disaster, environmentally and politically'. Raelin (2016:142) argues further: 'the intersubjective nature focuses far more on the consensual processes that encourage ongoing shared commitments among members of a community than on superimposed standards'.

In Table 1 we offered a framework to organisational leadership that was based on a neoliberal paradigm. Based on our analysis (notably re-framing, narration, mobilising and organising), we present-in Table 3-a revised framework for organisational leadership that is based on a sustainability paradigm.

\begin{tabular}{|l|l|l|l|}
\hline Frame/Interest/Power & Narration/Publics & Mobilising/Publics & Organising \\
\hline
\end{tabular}




\begin{tabular}{|l|l|l|l|}
\hline Leadership as a & Relational nature of a & Collective agency; utilisation & Disorganise: pluralism in the \\
collection of actors who & common & of common resources/Active; & plural sector \\
face a similar problem, & interest/Aware & & \\
recognise the problem, & & & \\
and organise themselves & & & \\
to do something about \\
it/Public/With and For; to
\end{tabular}

Table 3: Organisational Leadership: The Sustainability Paradigm

\section{Conclusion}

In this paper, we have argued for the need to replace the current neoliberal paradigm with a sustainability paradigm. In the context of the UN's (2015) Paris Agreement on Climate Change (Harvey, 2015; Hasina, 2016)—and the growing impact of stakeholder pressure on organisations (Patzer and Veogtlin, 2013)—-there is an increasing recognition that current dominant organisational leadership models are failing to work in the interests of social, economic and environmental sustainability. Moreover, we have suggested that the current framing of organisational leadership that is based (generally) on this neoliberal paradigm has contributed to an 'intolerable situation'.

We highlight again the views of Jeffrey Sachs who states that implementation of Paris 2015 now lies with politicians, businessmen, scientists, engineers and civil society. In detail, we consider that these people need to implement a new frame of organisational leadership that is based on a sustainability paradigm.

We have, therefore, attempted to re-frame organisational leadership based on Dewey's (1927) thoughts on publics, which—we consider-is wholly consistent with the need for greater stakeholder involvement in identifying how sustainability could be achieved. In addition, as the Paris Agreement has signalled, there is 
pressure from governments, campaigning groups and public opinion for organisations to expand their boundaries even further to interact with and take seriously the needs of the communities that they affect and their (organisations') impact on the natural environment.

With reference to the emerging social movements literature, we have suggested that this re-framing needs to be implemented via a renewed narrative, mobilisation and organisation.

Our paper concludes with a revised framework for organisational leadership that is based on a sustainability paradigm. In detail, we have offered analysis of the four sub-components namely framing, narration, organising and mobilising. 


\section{References}

Banerjee, S.B. and Bonnefous, A.M. (2011). Stakeholder management and sustainability strategies in the French nuclear industry. Business Strategy and the Environment, 20(2), pp.124-140.

Benford, R. D. and Snow, D. A. (2000). Framing Processes and Social Movements: An Overview and Assessment. Annual Review of Sociology, 26, 611-639.

Benn, S, Dunphy, D and Griffiths, A (2014) Organisational Change for Corporate Sustainability (3rd edition). Routledge: London.

Boje, D., Rosile, G., Durant, R., \& Luhman, J. (2004). Enron spectacles: A critical dramaturgical analysis. Organization Studies, 25(5), 751-774.

Bonini, S., \& Bové, A.B. (2014). Sustainability's strategic worth: McKinsey Global Survey results. McKinsey

Boyd, A., Burnes, B., Clark, E. and Nelson, A., 2013. Mobilising and organising for large scale change in healthcare: 'The Right Prescription: A Call to Action on the use of antipsychotic drugs for people with dementia'.

Branston, J. R., Rubini, L., Sugden, R., \& Wilson, J. R. (2006). The healthy development of economies: a strategic framework for competitiveness in the health industry. Review of Social Economy, 64(3), 301-329.

Burnes, B., Hughes, M., \& By, R. T. (2016). Reimagining organisational change leadership. Leadership, 1742715016662188.

Burnes, B. (2017a). After Paris: Changing corporate behaviour to achieve sustainability. Social Business. 2(3-4): 333-357

Burnes, B (2107b) Managing Change (7th Edition) Pearson: Harlow.

Burrell, G (1997) Organization paradigms. In A Sorge and M Warner (eds): The IEBM Handbook of Organizational Behaviour. International Thompson Business Press: London.

Carbo, J., Langella, I.M., Dao, V.T. and Haase, S.J., 2014. Breaking the ties that bind: From corporate sustainability to socially sustainable systems. Business and Society Review, 119(2), pp.175206. 
Card, C. (2004). The Atrocity Paradigm Applied to Environmental Evils. Ethics and the Environment. 9 (1), Spring 2004.

Case, P., Evans, L, S., Fabinyi, M., Cohen, P. J., Hicks, C. C., Prideaux, M., \& Mills, D. J. (2015). Rethinking environmental leadership: The social construction of leaders and leadership in discourse of ecological crisis, development and conversation. Leadership. 11(4): 396-423.

Castell, M. (2012) Networks of outrage and hope: Social movements in the internet age. Chicago, IL: Polity

Chomsky, N (1999) Profit Over People: Neoliberalism and Global Order. Seven Stories Press: New York, NY.

Collins, D (1998) Organizational Change. Routledge: London.

Crevani, L., Lindgren, M. and Packendorff, J., 2010. Leadership, not leaders: On the study of leadership as practices and interactions. Scandinavian Journal of Management. 26(1): 7-86.

Cunliffe, A. L., \& Eriksen, M. (2011). Relational leadership. Human Relations, 64(11), 1425-1449.

Dewey J (1927) The Public and its Problems. New York. Holt

Diamond, J (2005) Collapse: How Societies Choose to Fail or Survive. Allen Lane Penguin: New York, NY.

Docherty, P, Forslin, J, Shani, AB and King, M (2002) Emerging work systems: from intensive to sustainable. In P Docherty, J Forslin, AB Shani and M King (eds): Creating Sustainable Work Systems: Emerging perspectives and practices. Routledge: London.

Dunphy, DD and Griffiths, A (1998) The Sustainable Corporation: Organisational renewal in Australia. Allen \& Unwin: St Leonards, Australia.

Elkington, J (1994) Towards the sustainable corporation: Win-win-win Business strategies for sustainable development. California Management Review, 36(2), 90-100.

Elkington, J and Hartigan, P (2008) The Power of Unreasonable People: How Social Entrepreneurs Create Markets That Change the World. Harvard Business Press: Boston, MA.

Fairhurst, G. (2005). Reframing The Art of Framing: Problems and Prospects for Leadership. Leadership. 1 (2): 165-185

Freeman, R. E. (2010) Stakeholder theory: the state of the art. Cambridge. CUP 
Friedman, M (1970) The Social Responsibility of Business Is to Increase Its Profits. New York

Times Magazine, 13 September, 51-55

Fruin, WM (1992) The Japanese Enterprise System. Oxford University Press: Oxford.

Fry, LW and Nisiewicz, MS (2013) Maximising the Triple Bottom Line. Stanford University Press: Stanford, CA.

Fünfgeld H, and McEvoy D, (2014), Frame divergence in climate change adaptation policy: insights from Australian local government planning. Environment and Planning C: Government and Policy 32:603-622

Ganz M (2008). What is public narrative? (working paper) URL http://chutzpahportfolio.yolasite.com/resources/WhatIsPublicNarrative08.pdf

Ganz, M. (2010). Leading Change. Leadership, Organization, and Social Movements. In N Nohria and R Khurana (eds) Handbook of Leadership Theory and Practice. Boston: Harvard Business School Publishing.

Ghoshal S, Bartlett C, and Moran P (1999) A new manifesto for management. Sloan Management Review, 40(3): 9-20.

Gilbertson, T and Reyes, O (2009) Carbon Trading: How it Works and Why it Fails. Dag Hammerskjöld Foundation: Uppsala.

Gitlin, T. (1980). The Whole World Is Watching: Mass Media in the Making and Unmaking of the New Left. Berkely: University of California Press.

Gladwin, T. N., Kennelly, J. J., \& Krause, T. S. (1995). Shifting paradigms for sustainable development: Implications for management theory and research. Academy of Management Review, 20, 874-907.

Goffman, E. (1974). Frame analysis: An essay on the organization of experience. Harvard University Press.

Grint K (2005). Problems, problems, problems: The social construction of 'leadership'. Human Relations. 58(11): 1467-1494. 
Grunig, J. (1983). Communications behaviours and attitudes of environmental publics: Two studies. Journalism Monographs. 81. Association for Education in Journalism and Mass Communication Publications.

Gunter, M (2015) Where's the science? Businesses aren't setting the right climate targets to make a difference. The Guardian, 8 December. Available at www.the guardian.com.

Hall, J and Vredenburg, H (2003). The challenge of innovating for sustainable development. MIT Sloan Management Review, 45 (1), 61-68.

Hardin G (1968) The Tragedy of the Commons. Science, Vol 162: 1243-1248

Harvey, D (2005) A Brief History of Neoliberalism. Oxford University Press: Oxford.

Harvey, F (2015) Paris climate change agreement: the world's greatest diplomatic success. The Guardian, 14 December. Available at www.the guardian.com.

Hasina, S (2016) Climate Change after Paris: Developed Nations Must do Their Part. U.S. News and World Report, 18 January. Available at http://www.usnews.com/news/thereport/articles/2016-01-18/climate-change-after-paris.

Hess, C. (2008). Mapping New Commons. Presented at The Twelfth Biennial Conference of the International Association for the Study of the Commons, Cheltenham, UK, 14-18 July. URL http://surface.syr.edu/cgi/viewcontent.cgi?article=1023\&context=sul

Hockerts, K., \& Wüstenhagen, R. (2009). Greening Goliaths versus Emerging Davids. CBS Center for Corporate Social Responsibility.

IPCC (2014) Intergovernmental Panel on Climate Change: Climate Change 2014 - Synthesis Report. IPCC: Geneva. Available at https://www.ipcc.ch/report/ar5/syr/

Ioannou, I. and Serafeim, G. (2016). The consequences of mandatory corporate sustainability reporting: evidence from four countries.

Johnson, R and Ouchi, W (1974) Made in America (under Japanese management). Harvard Business Review, 52(5), 61-9.

Jones, ML (2012) Looking through the "green washing glass cage" of the green league table towards the sustainability challenge of UK universities. Journal of Organisational Change Management 25 (4), 630-647. 
Kemp, T (1990) The Climax of Capitalism: The US Economy in the Twentieth Century. Routledge: London.

Klein, N (2015) This Changes Everything: Capitalism vs The Climate. Simaon \& Schuster: New York: NY.

Kuhn, TS (1962) The Structure of Scientific Revolutions. University of Chicago Press: Chicago, IL. Leopold, A. (1949). A Sand County Almanac: And Sketches Here and There. Oxford University Press.

Lombardo, T, Schneider, S and Bryan, LK (2013) Corporate Leaders of Sustainable Organizations: Balancing Profit, Planet and People. In J Olson-Buchahan, LK Bryan and LK Thompson (Eds): Using Industrial-Organisational Psychology for the Greater Good: Helping Those Who Help Others. Routledge: New York, NY.

Lovelock, J. E., \& Margulis, L. (1974). Biological Modulation of the Earth's Atmosphere. Icarus. 21 (4): $471-489$

Marshall, J.D., \& Toffel, M.W. (2005). Framing the elusive concept of sustainability: a sustainability hierarchy. Environmental Science \& Technology. 39(3): 673-682

Martin, W (2016) Nobel Prize-winning economist Stiglitz tells us why 'neoliberalism is dead'. Business Insider UK, 19 August, available at http://uk.businessinsider.com/joseph-stiglitz-saysneoliberalism-is-dead-2016-8

Masayuki, M (1998) The end of the 'mass production system' and changes in work practices. In H Harukiyo and GD Hook (eds): Japanese Business Management: Restructuring for low growth and globalization. Routledge: London.

Mathur, VN; Afionis, S; Paavola, J; Andrew J. Dougill, AJ; and Stringer, LC (2014) Experiences of host communities with carbon market projects: towards multi-level climate justice. Climate Policy, 14 (1), 42-62.

Mink, OG (1992) Creating new organizational paradigms for change. International Journal of Quality and Reliability Management, 9(3), 21-35.

Mintzberg, H. (2016). Dis-organizing our way to balance. At: http://www.mintzberg.org/blog/world-social-forum-wrapup 
Montiel, I and Delgado-Ceballos, J (2014) Defining and Measuring Corporate Sustainability: Are We There Yet? Organization Environment, 27 (2), 113-139.

Morgan, G (1986) Images of Organizations. Sage: Beverly Hills, CA.

Ospina, S., and Foldy, E. G. (2010). Toward a Framework of Social Change Leadership. NYU Wagner Research Paper No. 2010-05.

Patzer and Veogtlin (2013) in Ethical leadership: Organisational Change, Leadership and Ethics: Leading Organizations Towards Sustainability, Eds. Bernard Burnes and Rune Todnem By, Routledge, 2012, pp. 9-34.

Piasecki, B (2012) Doing More With Less. Wiley: Hoboken, NJ.

Raelin, J, A. (2016). Imagine there are no leaders: Reframing leadership as a collaborative agency. Leadership 12 (2): 131-158

Reckwitz, A. (2002). Toward a Theory of Social Practices A Development in Culturalist Theorizing. European Journal of Social Theory 5(2): 243-263

Reed, M (1992) The Sociology of Organizations. Harvester Wheatsheaf: Hemel Hempstead.

Ricoeur, P. (1992). Oneself as another. University of Chicago Press.

Schaltegger, S; Lüdeke-Freund, F; and Hansen, EG (2012) Business cases for sustainability: the role of business model innovation for corporate sustainability. International Journal of Innovation and Sustainable Development, 6 (2), 95-119.

Schaltegger, S; Beckmann, M; and Hansen, EG (2013) Corporate Sustainability Meets Transdisciplinarity. Business Strategy and the Environment, 22 (4), 217-218.

Srinivasan, TN and Rethinaraj, TS (2013) Fukushima and thereafter: Reassessment of risks of nuclear power. Energy Policy, 52, 726-736.

Stiglitz, J (2010) Freefall: Free markets and the sinking of the global economy. Allen Lane: London. Storey, J (ed) (2004) Leadership in Organizations: Current issues and key trends. Routledge: London. Sugden, R. (2010). Public Interests Logic, Management Schools and Academics. Leadership and Cooperation in Academia Workshop. The University of Stirling, Scotland. October 2010. Summers \& Howieson 2014 The problem with leadership. Royal Society for the encouragement of Arts, Manufactures and Commerce 
Sutherland, N. (2015). Leadership Without Leaders. In B Carrol, J. Ford., and S. Taylor (Eds).

Leadership. London: SAGE Publications Ltd.

The Brundtland Report (1987) Report of the World Commission on Environment and Development:

Our Common Future. United Nations: New York, NY. Available at http://www.undocuments.net/our-common-future.pdf.

The Economist (2018). Sustainability Summit 2018. At: https://events.economist.com/eventsconferences/emea/sustainability-summit-2018

United Nations (2010) United Nations Global Compact. Available at www.unglobalcompact.org

United Nations (2015a) Resolution adopted by the General Assembly on 25 September 2015: 70/1. Transforming our world: the 2030 Agenda for Sustainable Development. United Nations: New York, NY. Available at ttp://www.un.org/ga/search/view_doc.asp?symbol=A/RES/70/1\&Lang=E

United Nation's (2015b) Sustainable Development Goals: 17 Goals to Transform out World. United Nations: New York, NY. Available at http://www.un.org/sustainabledevelopment/sustainabledevelopment-goals/

Vaggi G., \& Groenewegen P. (2003). A concise history of economic thought. Basingstoke: Palgrave MacMillan

Valente, M. (2012). Theorizing firm adoption of sustaincentrism. Organization Studies, 33, 563-591.

Wahie, A; Sinha, C; and Sinha, R. (2016). Social Movements as Methods of Social Change: A Study on the Delhi Experiment. Amity Business Review. Jul-Dec2016, Vol. 17 Issue 2, p89-95.

Willis P (2012) Engaging communities: Ostrom's economic commons, social capital and public relations. Public Relations Review 38: 116-122

WWF (2014) Living Planet Report 2014. WWF' available at wwf.org.uk

Yukl, G. Leadership in Organization ( $8^{\text {th }}$ Edition). Harlow: Pearson Education Limited.

Zalenzik, A. (1992). Managers and Leaders: Are They Different? Harvard Business Review. March-April 1992 Issue. 